\title{
ZOOPLANKTON SEBAGAI BIOINDIKATOR KESUBURAN PERAIRAN DI HUTAN MANGROVE TELUK CILETUH, KABUPATEN SUKABUMI
}

\author{
Indah Riyantini, Mochamad Rudyansyah Ismail, Yeni Mulyani, Gustiani \\ Departemen Kelautan, Fakultas Perikanan dan Ilmu Kelautan, Universitas Padjadjaran \\ Jl. Raya Bandung-Sumedang KM. 21 Jatinangor, Sumedang, Indonesia \\ E-mail: i.riyantini@unpad.ac.id
}

\begin{abstract}
ABSTRAK
Kawasan mangrove di Teluk Ciletuh dijadikan sebagai kawasan ekowisata mangrove. Kegiatan wisata ini menyebabkan terjadinya perubahan lingkungan di kawasan mangrove. Zooplankton dapat digunakan sebagai pengukur tingkat produktivitas suatu perairan. Tujuan dari penelitian ini untuk mengidentifikasi dan menghitung keanekaragaman serta kelimpahan zooplankton di Hutan mangrove perairan Teluk Ciletuh, sebagai bioindikator kesuburan perairan. Metode pengambilan data dilakukan secara purposive sampling. Pengambilan data dilakukan pada 3 stasiun penelitian berdasarkan komposisi mangrove yang berbeda dengan dua kali pengulangan. Terdapat 41 genus zooplankton yang didominansi oleh genus Cyclops sp. dengan nilai keanekaragaman sebesar 0,47 - 1,42. Kualitas air di perairan mangrove Teluk Ciletuh berada pada kondisi yang kurang produktif karena memiliki nilai $\mathrm{pH}$, salinitas, dan DO dibawah baku mutu perairan. Perairan tersebut memiliki status mesotrofik, dengan kelimpahan 7,39 - 72,06 ind/L. Berdasarkan kelimpahan zooplankton dan kualitas perairan, maka kesuburan perairan di Hutan Mangrove Teluk Ciletuh termasuk kategori cukup subur atau tingkat kesuburan sedang.
\end{abstract}

Kata kunci: Kelimpahan; Kesuburan; Mangrove; Mesotropik; Zooplankton.

\section{DIVERSITY AND ABUNDANCE OF ZOOPLANKTON IN VARIOUS MANGROVE COMPOSITIONS OF CILETUH BAY, SUKABUMI}

\begin{abstract}
The mangrove area in Ciletuh Bay is used as a mangrove ecotourism area. This tourism activity causes environmental changes in the mangrove area. Zooplankton can be used as a measure of the productivity level of a water. The purpose of this study was to identify and calculate the diversity and abundance of zooplankton in the mangrove forests of Ciletuh Bay waters, as bioindicators of aquatic fertility. The data collection method was done by using purposive sampling. Data were collected at 3 research stations based on different mangrove compositions with two repetitions. There are 41 zooplankton genera that are dominated by the genus Cyclops sp. with diversity values of 0.47 to 1.42 . The water quality in Ciletuh Bay mangrove waters is in a less productive condition because it has $\mathrm{pH}$, salinity, and DO values below the water quality standards. These waters have a mesotrophic status, with an abundance of 7.39 to 72.06 ind/L. Based on zooplankton agility and water quality, the fertility of the waters in the Ciletuh Bay Mangrove Forest is categorized as quite fertile or at a moderate level.
\end{abstract}

Key words: Abundance; Mangrove; Mesotrophic; Water Fertility; Zooplankton.

\section{PENDAHULUAN}

Teluk Ciletuh merupakan salah satu kawasan perairan estuarin yang memiliki vegetasi mangrove yang cukup luas. Kawasan Mangrove Ciletuh pernah dilakukan rehabilitasi pada tahun 2012, karena mengalami kerusakan. Saat ini, Kawasan mangrove di Teluk Ciletuh dijadikan tempat ekowisata. Perkembangan dan pembangunan disekitar objek ekowisata dapat menyebabkan terjadinya perubahan lingkungan Kawasan mangrove (Gunawan, 2017).

Pengelolaan Kawasan mangrove yang buruk dapat mengakibatkan terjadinya kerusakan (Kusmeri et al., 2015; Setyawan \& Winarno, 2006). Tingginya aktivitas wisata yang tidak terkontrol dengan baik membuat potensi sumber daya alam hayati dikawasan Teluk Ciletuh menjadi sangat rendah, seperti sulit ditemukannya flora dan fauna khas dan endemik di kawasan tersebut (Muhsimin et al., 2016). Secara biologi ekosistem mangrove berperan sebagai tempat pemijahan, tempat asuhan, tempat mencari makan dan tempat berlindung biota-biota perairan tertentu (Purnamasari, 2016; Redjeki, 2013). Sehingga keberadaan Kawasan mangrove sangat penting bagi kehidupan organisme perairan di Teluk Ciletuh.

Plankton dapat digunakan sebagai indikator biologi untuk mendeteksi terjadinya pencemaran atau penurunan kualitas perairan. Perairan yang tercemar menyebabkan perubahan struktur komunitas plankton terutama dalam hal keanekaragaman jenis (Fitriya, 2013). Zooplankton merupakan konsumen tingkat pertama yang memanfaatkan fitoplankton dan berperan sebagai penghubung dari produsen menuju hewan lain yang memiliki tingkatan lebih tinggi (Hasanah et al., 2014). Sehingga peran zooplankton cukup penting di perairan Kawasan mangrove. Zooplankton sangat sensitif terhadap perubahan lingkungan. Perubahan struktur komunitas mengindikasikan bahwa perairan tersebut telah mengalami penurunan, termasuk penurunan kesuburan perairan (Cole, 1998; Herwati, 
2019). Kelimpahan zooplankton mengindikasikan perairan yang subur di rawa banjiran Desa Sedang Kecamatan Suak Tapeh Kabupaten Banyuasin (Yusanti, 2019).

Belum adanya informasi yang mengkaji kesuburan perairan di Kawasan mangrove Teluk Ciletuh, sehingga perlu adanya penelitian tentang kesuburan perairan berdasarkan indikasi kelimpahan dan keanekaragaman zooplankton di kawasan mangrove Teluk Ciletuh perlu dilakukan. Penelitian ini menjadi informasi tingkat kesuburan perairan dan landasan pengelolaan Kawasan mangrove.

\section{METODE}

Penelitian ini menggunakan metode survey dengan teknik observasi langsung ke lapangan dan analisis di Laboratorium. Titik penentuan stasiun penelitian dilakukan dengan teknik purposive sampling yang dilakukan pada 3 stasiun berdasarkan dominansi jenis komposisi mangrove yang berbeda (Kusmeri \& Rosanti, 2015; Purnamasari, 2016). Terdapat dominansi mangrove Lumnitzera racemosa di Stasiun 1, dan dominansi mangrove Rhizophora mucronata di stasiun 2 dan 3. Lokasi penelitian ditunjukkan pada Gambar 1.

\section{Pengambilan sampel Zooplankton}

Pengambilan sampel dilakukan sebanyak 2 kali ulangan pada hari yang berbeda. Pada setiap sampling di stasiun diambil sebanyak 100 liter air yang diambil menggunakan ember berukuran 10 liter sebanyak 10 kali. Kedalaman perairan kurang dari 1 meter.

Air disaring menggunakan plankton net no. 25 yang dilengkapi dengan tabung pengumpul plankton berukuran $50 \mathrm{ml}$. Sampel plankton disimpan dalam botol sampel kemudian ditambahkan pengawet lugol agar sampel tidak rusak dan disimpan didalam coolbox (Fachrul, 2007; Hardiyanto \& Suherman, 2012; Junaidi et al., 2018; Kusmeri \& Rosanti, 2015; Manurung \& Setyawati, 2015; Nurhasanah et al., 2017; Yusanti, 2019).

\section{Identifikasi Zooplankton}

Identifikasi zooplankton dilakukan secara exsitu di Laboratorium Kualitas Air Pusat Penelitian dan Pengembangan Sumber Daya Alam dan Lingkungan (PPSDAL) Universitas Padjadjaran. Sampel kemudian dianalisis menggunakan mikroskop dengan perbesaran 100 kali pada Sedgwick rafter/cover glass. Identifikasi zooplankton menggunakan buku identifikasi plankton (Sachlan, 1982).

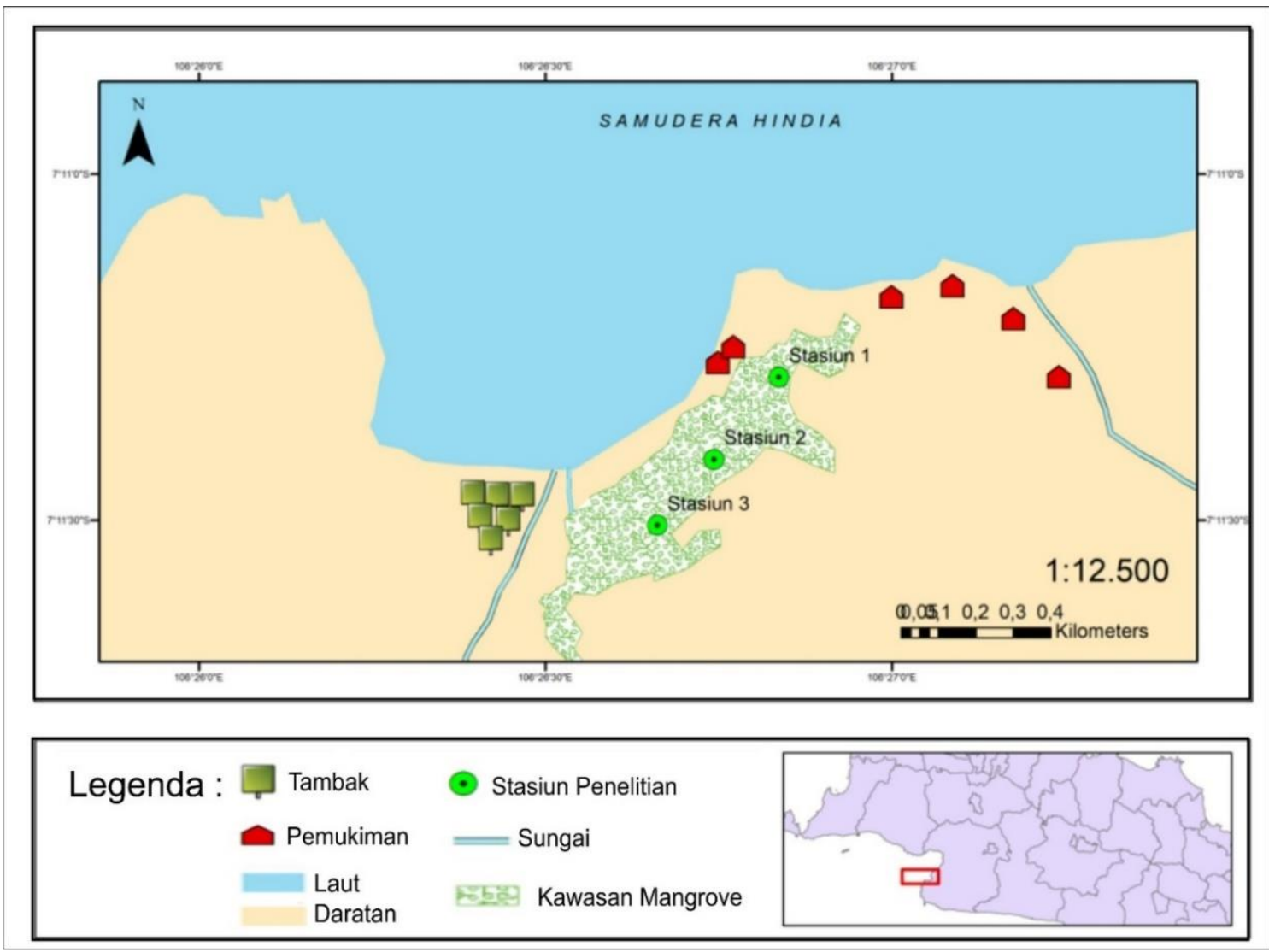

Gambar 1 Peta lokasi penelitian. 


\section{Pengukuran Kualitas Air}

Parameter kualitas air yang diukur dalam penelitian ini meliputi suhu, $\mathrm{pH}$, salinitas, DO dan kecerahan. Pengukuran pH dilakukan metode SNI 066989.11-2004 Yaitu mengunakan alat pH meter. Pengukuran salinitas dilakukan secara in situ menggunakan alat Refraktometer. Pengukuran suhu dilakukan menggunakan metode pemuaian yaitu dengan mencelupkan alat termometer berskala celcius kedalam air sampai menunjukan angka yang stabil. Pengukuran kecerahan air diukur menggunakan alat secchi disk yang dimasukan kedalam air sampai batas sechi disk tidak dapat terlihat lagi oleh mata. DO diukur secara insitu menggunakan DO meter yang dicelupkan langsung ke dalam perairan. Pengukuran parameter ini akan dibandingkan dengan baku mutu kualitas perairan di Kawasan mangrove atau daerah estuarin.

\section{Parameter Zooplankton}

Menurut Fachrul (2007) dan Sachlan (1982) kelimpahan plankton dihitung berdasarkan rumus :

Keterangan :

$$
\mathrm{N}=\mathrm{n} \times\left(\frac{\mathrm{Vr}}{\mathrm{Vo}_{\mathrm{o}}}\right) \times\left(\frac{1000}{\mathrm{Vs}}\right)
$$

$\mathrm{N}=$ Jumlah individu per liter

$\mathrm{n} \quad$ = Jumlah individu yang diamati

$\mathrm{Vr} \quad=$ Volume air yang tersaring $(\mathrm{ml})$

Vo = Volume air yang diamati pada counting chamber $(\mathrm{ml})$

Vs = Volume air yang disaring (Liter)

Indeks Keanekaragaman Shannon-Wiener (Fachrul, 2007):

$$
\mathrm{H}^{\prime}=-\sum_{\mathrm{i}=1}^{\mathrm{S}} \mathrm{Pi} \text { Ln Pi }
$$

Keterangan :

$$
\begin{aligned}
\mathrm{H}^{\prime} & =\text { Indeks keanekarangan Shannon-Wiener } \\
\mathrm{Pi} & =\text { ni/N } \\
\mathrm{ni} & =\text { Kelimpahan jenis pada peringkat ke-i } \\
\mathrm{N} & =\text { Kelimpahan total } \\
\mathrm{S} & =\text { jumlah spesies }
\end{aligned}
$$

Indeks Keseragaman :

$$
\mathrm{E}=\frac{\mathrm{H}^{\prime}}{\mathrm{H} \mathrm{maks}}
$$

Keterangan :

$\mathrm{E} \quad=$ Indeks keseragaman

$\mathrm{H}^{\prime} \quad=$ Indeks keanekaragaman

$\mathrm{H}$ maks $=\mathrm{Ln} \mathrm{S}$

$\mathrm{S} \quad=$ Jumlah spesies

Indeks Dominansi :

$$
\mathrm{C}=\sum(\mathrm{ni} / \mathrm{N})^{2}
$$

Keterangan :

$\mathrm{C}=$ Indeks dominansi Simpson

ni = Jumlah individu ke-i

$\mathrm{N}$ = Jumlah total individu semua jenis

\section{Pendugaan Status Perairan}

Pendugaan status perairan dilakukan dengan pengukuran kelimpahan zooplankton berdasarkan acuan dari (Goldman \& Horne, 1994), yaitu :

- Oligotrofik yaitu perairan tersebut mempunyai tingkat kesuburan rendah dengan kelimpahan zooplankton kurang dari 1 ind/lt,

- Mesotrofik yaitu perairan yang mempunyai tingkat kesuburan sedang dengan kelimpahan zooplankton antara 1-500 ind/lt,

- Eutrofik yaitu perairan yang mempunyai tingkat kesuburan tinggi dengan kelimpahan zooplankton lebih dari 500 ind/lt.

\section{HASIL DAN PEMBAHASAN}

Hasil pengamatan secara visual di stasiun 2 dan 3, terlihat bahwa kerapatan mangrove cukup tinggi

\begin{tabular}{|c|c|c|c|c|c|c|}
\hline Stasiun & $\begin{array}{c}\text { Suhu } \\
\left({ }^{\circ} \mathrm{C}\right)\end{array}$ & $\mathrm{pH}$ & $\begin{array}{c}\text { Salinitas } \\
(\% 0)\end{array}$ & $\begin{array}{c}\mathrm{DO} \\
(\mathrm{mg} / \mathrm{l})\end{array}$ & Kecerahan & Kedalaman \\
\hline 1 & 28 & 5,28 & 4 & 2,5 & $70 \mathrm{~cm}$ & $\pm 1 \mathrm{~m}$ \\
\hline 2 & 26,5 & 5,20 & 4 & 1,8 & Sampai dasar & $\pm 50 \mathrm{~cm}$ \\
\hline 3 & 27 & 5,16 & 0 & 5,4 & Sampai dasar & $\pm 50 \mathrm{~cm}$ \\
\hline $\begin{array}{c}\text { Baku Mutu } \\
\text { (KepMen LH No. 51, } \\
\text { 2004)* }\end{array}$ & $28-32$ & $7-8,5$ & $0-34$ & $>5$ & - & - \\
\hline
\end{tabular}
karena merupakan kawasan mangrove hasil rehabilitasi sehingga perairan yang ada didalamnya pun selalu teduh dan tidak terpapar cahaya matahari secara langsung. Namun jika dibandingkan dengan kerapatan di stasiun 1, kerapatannya lebih rendah. Pengukuran kualitas perairan menunjukkan hasil seperti yang disajikan pada Tabel 1 .

Tabel 1 Parameter fisik dan kimia perairan mangrove Teluk Ciletuh dan baku mutu perairan.

\footnotetext{
*Untuk organisme
} 
Kondisi pada stasiun 1 adalah genangan air paling banyak karena wilayahnya yang paling rendah dengan kedalaman 1 meter. Sehingga air hujan yang tergenang di lokasi tersebut dapat tertampung lebih banyak dibanding lokasi lainnya. Pada stasiun 2 perairan menujukkan nilai $\mathrm{pH} 5,20$ nilai ini juga merupakan nilai $\mathrm{pH}$ dibawah baku mutu perairan. Sedangkan pada stasiun 3 memiliki nilai $\mathrm{pH}$ perairan 5,16 . Sedangkan untuk kadar asam yang optimal dalam pertumbuhan mangrove berkisar antara $6 \mathrm{~s} / \mathrm{d} 9$ (Andarani et al., 2016).

Pada stasiun 2 dan 3 kondisi perairannya sangat sedikit, perairan yang ada pada kedua lokasi tersebut seperti genangan air yang kecil dan terpisahpisah karena kondisi geografis tanahnya yang tidak datar. Kedua lokasi tersebut juga sulit dijangkau oleh pasang surut air laut karena letaknya yang terhalang oleh tanah timbul disekitar pantai. Sehingga air yang tergenang pada setiap stasiun penelitian diduga sebagian besar merupakan air hujan yang terperangkap pada ekosistem mangrove dan tidak bisa keluar menuju arah laut karena terhalang oleh tanah timbul tersebut. Hal tersebut sesuai dengan pernyataan dari Wardhani \& Ihwan (2015) yang menyatakan bahwa $\mathrm{pH}$ air hujan secara alami berkisar antara 3-5,6. Sehingga nilai $\mathrm{pH}$ yang didapat pada pengukuran di perairan Teluk Ciletuh lebih mendekati $\mathrm{pH}$ air hujan karena pada saat waktu pengambilan data dilakukan masih berada pada musim peralihan dari musim hujan menuju musim kemarau dan masih sering terjadi hujan pada sore dan malam hari.

Salinitas perairan mangrove pada setiap stasiun menunjukkan nilai yang sangat rendah untuk daerah pesisir. Pada stasiun satu dan dua salinitasnya menunjukan nilai 4 ppt sedangkan pada stasiun 3 memiliki nilai 0 , yang mana nilai tersebut menunjukan bahwa air yang ada di lokasi penelitian lebih dominan dipengaruhi oleh air tawar. Hal tersebut dikarenakan oleh adanya tanah timbul yang menghalangi masuknya air laut kedalam ekosistem mangrove dan kondisi perairan mangrove yang selalu teduh sehingga penguapan yang terjadi sangat kecil. Selain itu pada saat penelitian berlangsung keadaan laut bukan pada saat pasang air laut tertinggi. Sehingga perairan mangrove tersebut benar-benar tidak terpengaruh oleh air laut secara langsung. Pada malam sebelum pengambilan data berlangsung juga terjadi hujan cukup deras sehingga air hujan tersebutlah yang sangat mempengaruhi perairan mangrove tersebut. Nilai salinitas yang rendah juga didukung oleh hasil penelitian yang menunjukkan bahwa jenis zooplankton yang banyak di temukan di setiap stasiun penelitian lebih didominasi oleh jenis zooplankton yang memliki toleransi salinitas cukup rendah, sehingga dapat hidup di air tawar, payau, maupun laut.

Hasil pengukuran DO pada lokasi penelitian menunjukkan bahwa DO pada perairan mangrove Teluk Ciletuh yang diambil pada 3 stasiun penelitian berkisar antara 1,8 -5,4 mg/L. Pada stasiun satu memiliki nilai DO $2,5 \mathrm{mg} / \mathrm{L}$ sedangkan pada stasiun 2 memliki $1,8 \mathrm{mg} / \mathrm{L}$ nilai tersebut menunjukkan bahwa nilai DO pada kedua stasiun tersebut memiliki nilai yang rendah dan berada dibawah baku mutu perairan. Hal tersebut diduga karena perairan yang tidak di pengaruhi oleh arus dan angin sehingga proses pencampuran udara dan air sangat sulit terjadi, selain itu tidak banyak ditemukan tumbuhan air yang tumbuh pada perairan tersebut sehingga tidak banyak proses fotosintesis yang tejadi dalam air. Padatnya vegetasi mangrove pada setiap stasiun juga membuat cahaya matahari tidak dapat masuk secara langsung ke perairan sehingga proses fotosintesis yang dilakukan oleh tumbuhan maupun fitoplankton tidak dapat berlangsung secara optimal.

Pada stasiun 3 nilai DO memiliki nilai yang paling tinggi dibanding stasiun lainnya yaitu memiliki nilai $5,4 \mathrm{mg} / \mathrm{L}$. Nilai tersebut memenuhi syarat baku mutu perairan untuk tempat hidup biota. Kandungan nilai DO tersebut dikarenakan stasiun 3 merupakan stasiun yang memiliki volume air paling sedikit dibanding perairan lainnya, sehingga proses pencampuran udara dan air dapat lebih mudah terjadi. Selain itu proses pengukuran kualitas air pada stasiun 3 dilakukan pada hari yang berbeda, yang mana sehari sebelum dilakukan pengambilan data pada stasiun 3 telah terjadi hujan deras sehingga membantu proses pencampuran air dengan udara. Stasiun 3 juga merupakan stasiun yang paling jauh dengan pemukiman warga, sehingga kontaminasi pencemaran limbah jauh lebih sedikit dibanding stasiun lainnya.

Kecerahan perairan pada ekosistem mangrove di Teluk Ciletuh memiliki kecerahan yang tinggi . Hal tersebut ditunjukkan oleh pengukuran kecerahan yang dilakukan pada setiap stasiun penelitian. Hal tersebut karena perairan tersebut memiliki kedalaman yang rendah dan perairannyapun tenang serta jarang tersentuh oleh aktivitas manusia. Sedangkan pada stasiun 1 yang memiliki kedalaman satu meter kecerahannya mencapai $70 \mathrm{~cm}$. hal tersebut dikarenakan stasiun 1 merupakan lokasi tempat bertemunya semua perairan mangrove karena kondisi geografisnya yang paling rendah dibanding stasiun lainnya. Selain itu, penelitian ini dilakukan pada saat musim peralihan dimana masih sering terjadi hujan dan dasar perairan yang berupa lumpur membuat dasar perairan membutuhkan waktu yang cukup lama untuk dapat mengendap. Cahaya matahari tidak dapat menembus dasar perairan jika kosentrasi bahan tersuspensi atau terlarutnya tinggi. Kecerahan mempengaruhi distribusi dari zooplankton (Amri et al., 2020). Baku mutu mengacu pada kepmen LH No. 51 tahun 2004 mengenai baku mutu organisme di perairan mangrove, maka kondisi perairan mangrove tersebut dalam kondisi yang kurang produktif karena memiliki nilai $\mathrm{pH}$, salinitas, dan DO dibawah baku mutu perairan. Sehingga dalam pengamatan di lapang, kondisi perairan tidak didapati ikan atau sedikit sekali organisme yang hidup di Kawasan mangrove tersebut.

\section{Kelimpahan Zooplankton}

Nilai kelimpahan zooplankton tertinggi berada pada stasiun 3, yang mana memiliki 
komposisi mangrove yang di dominasi oleh jenis Rhizophora mucronata dengan dominansi jenis zooplankton adalah Cyclops sp. dan Coleps sp. Pada stasiun 3, komposisi mangrove cukup rapat, dan kapasitas air yang ada di sana paling sedikit dibanding stasiun lainnya. Sehingga semua zooplankton yang terdapat dilokasi tersebut berkumpul dan terfokus disuatu perairan yang sedikit. Selain itu stasiun 3 merupakan stasiun yang memiliki nilai DO perairan yang paling optimal untuk kelangsungan biota perairan dan mendekati baku mutu perairan menurut kepmen
LH No. 51 tahun 2004. Meskipun memiliki nilai salinitas 0, namun kelimpahan zooplankton pada stasiun 3 adalah yang paling tinggi dibanding stasiun lainnya. Hal ini karena jenis zooplankton yang ditemukan pada setiap stasiun lebih didominasi oleh zooplankton yang dapat beradaptasi secara luas untuk hidup di air tawar, payau maupun laut seperti Cyclops sp. dan Coleps sp., sehingga zooplankton tersebut dapat hidup melimpah pada lokasi tersebut. Identifikasi jenis zooplankton yang ditemukan pada setiap stasiun penelitian di sajikan pada Tabel 2 .

Tabel 2 Hasil identifikasi zooplankton pada setiap stasiun penelitian.

\begin{tabular}{|c|c|c|c|c|}
\hline \multirow{2}{*}{ No } & \multirow{2}{*}{ Jenis Zooplankton } & \multicolumn{3}{|c|}{ Jumlah (ind/100 liter) } \\
\hline & & Stasiun 1 & Stasiun 2 & Stasiun 3 \\
\hline 1 & Amoeba & 15 & 13 & - \\
\hline 2 & Arshella & 5 & 81 & 3 \\
\hline 3 & Brachionus & 2 & 6 & 2 \\
\hline 4 & Bryocamptus & - & 1 & - \\
\hline 5 & Bursaria & 8 & 2 & - \\
\hline 6 & Canthocampus & 1 & - & - \\
\hline 7 & Centropyxis & 2 & 1 & - \\
\hline 8 & Chironomus & - & - & 1 \\
\hline 9 & Cyrtolophosis & - & 8 & - \\
\hline 10 & Chydorus & 2 & - & 1 \\
\hline 11 & Cyclops & 612 & 546 & 1.803 \\
\hline 12 & Cypria & - & - & 1 \\
\hline 13 & Cypridopsis & 3 & - & - \\
\hline 14 & Coleps & 21 & 4 & 5.214 \\
\hline 15 & Colurella & - & 2 & - \\
\hline 16 & Diaptomus & - & - & 84 \\
\hline 17 & Euglypa & - & 1 & 1 \\
\hline 18 & Tanytarsus & - & 1 & - \\
\hline 19 & Globorotalia & - & 1 & - \\
\hline 20 & Ichtydium & 5 & 3 & - \\
\hline 21 & Keratella & 2 & - & 2 \\
\hline 22 & Lecane & - & 2 & - \\
\hline 23 & Lepadela & 1 & 2 & 1 \\
\hline 24 & Lionotus & - & 1 & - \\
\hline 25 & Moina & - & - & 1 \\
\hline 26 & Monostyla & 2 & 2 & 1 \\
\hline 27 & Nauplius & 54 & 178 & 50 \\
\hline 28 & Nebela & - & 1 & - \\
\hline 29 & Notholca & 2 & 5 & 3 \\
\hline 30 & Paramecium & 38 & 4 & 32 \\
\hline 31 & Philodina & 3 & 3 & 3 \\
\hline 32 & Panagrellus & 5 & 2 & 2 \\
\hline 33 & Peridinium & - & 2 & - \\
\hline 34 & Platiyas & 1 & 5 & - \\
\hline 35 & Plumatela & 1 & - & - \\
\hline 36 & Polyartra & 2 & 1 & - \\
\hline 37 & Rotaria & - & 4 & - \\
\hline 38 & Stentor & - & 15 & 3 \\
\hline 39 & Stylonychia & 4 & 2 & 16 \\
\hline 40 & Squatinella & 3 & 13 & - \\
\hline 41 & Tetrahymena & 1 & 3 & - \\
\hline 42 & Vorticella & - & 2 & - \\
\hline & Total & 793 & 912 & 7.223 \\
\hline
\end{tabular}


Stasiun 1 merupakan stasiun yang memiliki kelimpahan zooplankton paling sedikit dibanding stasiun lainnya. Perairannya tergenang di tengah vegetasi mangrove dengan dominansi jenis mangrove adalah Lumnitzera racemosa. Pada pengamatan menunjukkan kelimpahan zooplankton sebesar 7,93 ind/L. Hal tersebut diduga karena kerapatan mangrove pada stasiun satu memiliki kerapatan yang paling rendah dan volume perairan yang cukup banyak dibanding stasiun lainnya dengan kedalaman yang paling dalam yaitu 1 meter. Kondisi hujan besar berakibat pada penambahan volume air di stasiun 1 ini. Adapun jenis zooplankton yang mendominasi pada stasiun 1 adalah Cyclops sp.

Pada stasiun stasiun 2 nilai kelimpahan menunjukan nilai 9,12 ind/L. Stasiun 2 merupakan daerah yang memiliki kerapatan mangrove cukup tinggi dengan dominansi mangrove terbanyak adalah jenis Rhizophora mucronata. Jenis plankton yang mendominasi adalah Cyclops sp. Stasiun 2 terletak diantara stasiun 1 dan 3 serta memiliki volume perairan yang sedikit dengan kedalaman maksimal adalah $50 \mathrm{~cm}$. Stasiun 3 menjadi tempat yang memiliki kelimpahan zooplankton yang paling banyak, yaitu $72,23 \mathrm{in} / \mathrm{L}$. Jenis zooplankton yang paling banyak ditemukan adalah Coleps sp. Stasiun 3 merupakan daerah yang memiliki kerapatan mangrove cukup tinggi dengan dominansi mangrove terbanyak adalah jenis Rhizophora mucronata. Beberapa bentuk zooplankton ditunjukkan pada Gambar 2.

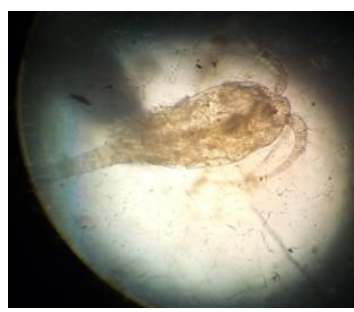

(a)

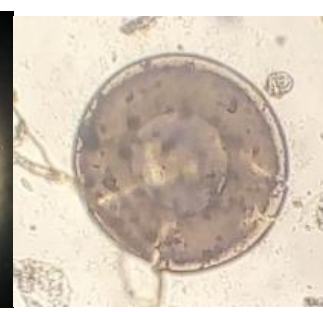

(b)

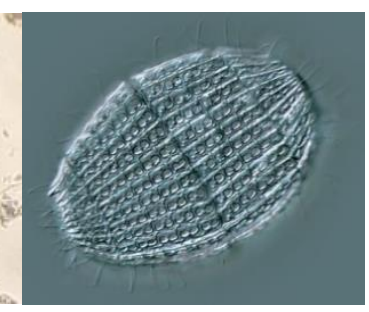

(c)

Gambar 2 Beberapa bentuk zooplankton: (a) Cyclops sp. (b) Arshella sp. dan (c) Coleps sp.

Secara umum nilai kelimpahan zooplankton di perairan mangrove Teluk Ciletuh tergolong dalam kategori rendah hingga sedang. Menurut Pongngarang (2018) kelimpahan zooplankton dapat menentukan kesuburan suatu perairan. Zooplankton di ketiga stasiun memiliki kelimpahan yang berbeda, karena kodisi perairan yang tidak mendukung zooplankton untuk hidup dan berkembang biak. Pada stasiun 3, kelimpahan zooplankton yang cukup banyak, terutama dari jenis Coleps, mengindikasikan bahwa zooplankton dapat hidup dengan baik di perairan tersebut (Herwati, 2019; Yusanti, 2019).

Hasil identifikasi zooplankton menunjukkan bahwa jenis zooplankton yang mendominasi adalah jenis Cyclops sp. Hal ini didukung oleh pernyataan Djohan (2010) dan Gao et al. (2011), bahwa jenis zooplankton yang paling melimpah di estuari adalah jenis copepod karena mudah beradaptasi dengan baik pada lingkungannya, serta dapat hidup di perairan tawar, payau maupun laut. Jenis zooplankton yang termasuk dalam subkelas Copepod itu salah satunya adalah Cyclops sp. Sehingga tidak heran jika Cyclops merupakan zooplankton yang paling banyak ditemukan di seluruh perairan.

\section{Keanekaragaman Zooplankton}

Nilai keanekaragaman jenis zooplankton di Teluk Ciletuh termasuk dalam kategori rendah hingga sedang. Stasiun dua merupakan stasiun yang memiliki nilai keanekaragaman paling tinggi dibanding stasiun lainnya dengan nilai keanekaragaman sebesar 1,42 pada pengamatan hari ke-1 dan 1,21 pada pengamatan hari ke-2. Nilai tersebut termasuk kategori perairan yang memiliki nilai keanekaragaman zooplankton sedang, dengan kestabilan komunitas sedang. Terdapat 33 jenis zooplankton yang ditemukan pada stasiun tersebut.

Nilai rata-rata keanekaragaman yang paling rendah berada pada stasiun 3 , yang mana memiliki nilai 0,47 . Hal tersebut dikarenakan stasiun 3 memiliki perairan yang paling sedikit seperti genangan air dengan ukuran lebar 1-3 meter dengan kedalaman maksimal $\pm 50 \mathrm{~cm}$ dan tidak banyak biota yang dapat hidup di perairan tersebut karena persaingan makanan dan daya adaptasi lingkungannya. Stasiun 3 memiliki salinitas 0 ppt karena perairannya hanya dipengaruhi oleh air hujan dan tergenang di Kawasan mangrove tersebut. Sehingga stasiun 3 lebih banyak didominasi oleh zooplankton air tawar dan payau yang dapat beradaptasi dengan salinitas yang rendah.

Menurut Hader \& Gao (2015) nilai keanekaragaman yang semakin kecil menunjukan semakin tingginya pencemaran di daerah tersebut. Namun berdasarkan hasil pengamatan yang dilakukan tidak terdapat industri pabrik atau aktivitas warga yang menyebabkan pencemaran pada lokasi penelitian. Faktor lain yang menyebabkan rendahnya nilai keanekaragaman zooplankton pada lokasi penelitian adalah kualitas perairannya yang tidak begitu bagus untuk kelangsungan hidup zooplankton, sehingga hanya jenis-jenis tertentu saja yang dapat beradaptasi dengan kondisi tersebut.

Menurut Sachlan (1982) salinitas optimal untuk kelangsungan hidup plankton >20 ppt. Sedangkan pada setiap stasiun penelitian salinitas perairan menunjukan nilai 0-4 ppt. Hal tersebut menunjukan bahwa salinitas tersebut tidak sesuai untuk kelangsungan zooplankton di perairan payau atau Kawasan mangrove. Sehingga terdapat banyak jenis zooplankton air tawar yang lebih mendominasi 
(Nurruhwati et al, 2017). Selain nilai salinitas yang rendah, nilai $\mathrm{pH}$ pada perairan mangrove Teluk Ciletuh juga memiliki nilai yang rendah yaitu berkisar antara 5,16 - 5,28. pH. Hal ini menunjukan bahwa, Kawasan mangrove di Teluk Ciletuh sangat dipengaruhi oleh $\mathrm{pH}$ air hujan (Wardhani \& Ihwan, 2015). Nilai pH optimum untuk kelangsungan hidup plankton berkisar antara 5,6-9,4. Sehingga nilai $\mathrm{pH}$ pada lokasi penelitian kurang sesuai dengan standar pH untuk tempat hidup plankton.

Nilai DO pada lokasi penelitianpun tergolong sangat rendah dengan nilai DO berkisar antara 1,8-5,4 ppm. Kandungan oksigen terlarut yang optimum di perairan adalah 5,7-8,5 ppm. Jika nilai DO <5ppm maka perairan tersebut termasuk kategori tidak produktif sedangkan jika nilai DO berkisar antar 5-7 ppm maka perairan tersebut dikategorikan kedalam golongan perairan yang kurang produktif. Menurut Kepmen LH No. 51 tahun 2004 nilai DO pada lokasi penelitian tidak termasuk nilai yang sesuai dengan baku mutu perairan untuk biota laut karena tidak lebih besar dari 6. Maka dari itu nilai keanekaragaman yang rendah diduga karena kualitas perairan yang kurang produktif untuk kelangsungan zooplankton.

\section{Keseragaman Zooplankton}

Ketiga stasiun penelitian menunjukkan bahwa indeks keseragaman zooplankton termasuk kedalam kategori rendah, dengan penyebaran jumlah spesies yang tidak sama. Rendahnya nilai keseragaman suatu biota di suatu ekosistem menunjukan bahwa ketersediaan dan pemanfaatan nutrisi pada daerah tersebut juga rendah (Purnamasari, 2016). Sehingga dapat dikatakan bahwa perairan mangrove Teluk Ciletuh kurang cocok untuk kehidupan organisme perairan, karena rendahnya nutrisi di perairan tersebut. Besar nilai keseragaman zooplankton di ketiga stasiun penelitian ditunjukkan pada Tabel 3.

Tabel 3 Nilai keseragaman zooplankton di Teluk Ciletuh.

\begin{tabular}{cc}
\hline Stasiun & $\begin{array}{c}\text { Keseragaman } \\
\text { Zooplankton }\end{array}$ \\
\hline 1 & 0,32 \\
2 & 0,41 \\
3 & 0,21 \\
\hline
\end{tabular}

\section{Dominansi Zooplankton}

Nilai dominansi menunjukkan bahwa terdapat jenis zooplankton yang mendominasi perairan mangrove Teluk Ciletuh. Nilai dominansi yang mendekati 1 menyatakan bahwa terdapat spesies yang mendominasi spesies lainnya pada suatu populasi, sehingga komunitasnya tergolong labil dan terdapat tekanan ekologis. Indeks dominansi yang paling tinggi berada pada stasiun 3 dengan jenis zooplankton yang mendominasi adalah Cyclops sp. dan Coleps sp. Jenis tersebut memang merupakan jenis zooplankton yang pada umumnya paling melimpah di seluruh perairan tawar dan laut. Nilai dominansi zooplankton yang dihasilkan dari ketiga stasiun ditunjukkan pada Tabel 4.

Pada stasiun 1 yang memiliki dominansi jenis mangrove Lumnitzera racemosa kelimpahan zooplankton yang paling mendominasi adalah genus Cyclops sp. yang merupakan subkelas dari Copepod. Sedangkan pada stasiun 2 yang memiliki nilai keseragaman paling tinggi, terdapat tiga jenis zooplankton yang mendominasi stasiun tersebut yaitu Cyclops, Nauplius, dan Arshella yang mana Cyclops dan Nauplius merupakan zooplankton yang memiliki toleransi tinggi terhadap salinitas sehingga dapat hidup pada perairan tawar, payau maupun laut. Sedangkan Arcella merupakan jenis zooplankton yang hanya dapat hidup di air tawar. Pada stasiun 3 kelimpahan zooplankton yang paling tinggi hanya didominasi oleh dua jenis yaitu Cyclops dan yang paling tinggi adalah dari genus Coleps sp. kedua jenis zooplankton tersebut merupakan zooplankton yang dapat hidup di air tawar maupun air laut. Sehingga dapat tumbuh dan melimpah pada perairan di stasiun tersebut meskipun memiliki nilai salinitas 0 .

Tabel 4. Nilai Dominansi Zooplankton Di Teluk Ciletuh

\begin{tabular}{cc}
\hline Stasiun & Dominansi Zooplankton \\
\hline 1 & 0,62 \\
2 & 0,44 \\
3 & 0,74 \\
\hline
\end{tabular}

\section{Kesuburan Perairan}

Kesuburan perairan mangrove terbilang sedang atau pada tingkat mesotrofik, dimana kelimpahan zooplankton berada pada $1-500$ ind/L (Goldman \& Horne, 1994). Terlihat dari keanekaragaman dan keseragaman, perairan kurang baik untuk organisme perairan, karena kualitas perairan yang dibawah baku kehidupan organisme perairan estuarin (Yusanti, 2019).

\section{SIMPULAN}

Kelimpahan zooplankton Stasiun 1 sebesar 7,93 ind/L, stasiun 2 sebesar 9,12 ind/L, dan stasiun 3 sebesar 72, 23 in/L. Kelimpahan zooplankton tersebut menunjukkan perairan mesotrofik dengan keanekaragaman rendah hingga sedang, yaitu 0,47 1,42 . Perairan tersebut pun kurang baik untuk organisme perairan lainnya, karena mengindikasikan perairan yang miskin akan nutrisi. Jenis zooplankton yang paling mendominasi adalah Cyclops sp.

\section{DAFTAR PUSTAKA}

Amri K, Ma'un A, Priatna A, Suman A, Prianto E \& Muchlizar. (2020). Sebaran Spasial, Kelimpahan dan Struktur Komunitas Zooplankton di Estuari Sungai Siak serta Faktor-Faktor yang Mempengaruhinya. Jurnal Akuatika Indonesia, 5, (1), 7-19.

Andarani T, Hastuti ED \& Budihastuti R. (2016). Perubahan Kualitas Air dan Hubungannya 
dengan Pertumbuhan Semai Rhizophora mucronata Lamk. Berdasarkan Waktu Pengamatan yang Berbeda pada Saluran Tambak Wanamina. Jurnal Biologi, 5, (1), 7281.

Cole GA. (1998). Limnology : In Hydrology and Lakes. Dordrecht: Springer Netherlands.

Djohan TS. (2010). Dinamika Komunitas Plankton di Perairan Ekosistem Hutan Bakau Segara Anakan yang Sedang Berubah. Jurnal Manusia dan Lingkungan, 3, (17), 135-149.

Eddy S, Mulyana A, Ridho MR \& Iskandar I. (2015). Degradasi Hutan Mangrove di Indonesia. Jurnal Lingkungan dan Pembangunan, 1, (3), 240254.

Fachrul MF. (2007). Metode Sampling Bioekologi. Jakarta: Bumi Aksara.

Fitriya N. (2013). Komunitas Zooplankton di Perairan Lamalera dan Laut Sawu, Nusa Tenggara Timur. Jurnal Ilmu dan Teknologi Kelautan Tropis, 5, (1), 219-227.

Gao X, Song J \& Li X. (2011). Zooplankton Spatial and Diurnal Variations in The Changjiang River Estuary Before Operation of The Three Gorges Dam. China Journal Ocean Limnology, 29, (3), 591-602.

Goldman C \& Horne, A. (1994). Limnology. USA: Mc. Graw Hill Book Co.

Gunawan H. (2017). Dynamics of Mangrove Community in Revegetation Area of Karangsong, North Coast of Indramayu District, West Java, Indonesia. Biodiversitas, Journal of Biological Diversity, 18, (2), 659-665.

Hader DP \& Gao K. (2015). Interactions of Anthropogenic Stress Factors on Marine Phytoplankton. Frontier Environment Science, 3, (14), 1-14.

Hardiyanto R \& Suherman H. (2012). Kajian Produktivitas Primer Fitoplankton di Waduk Saguling, Desa Bongas dalam Kaitannya dengan Kegiatan Perikanan. Jurnal Perikanan dan Kelautan, 3, (4), 51-59.

Hasanah AN, Rukminasari N \& Sitepu FG. (2014). Perbandingan Kelimpahan Struktur Komunitas Zooplankton di Pulau Kodingareng dan Lanyukang, Kota Makasar. Torani (Jurnal Ilmu Kelautan dan Perikanan), 24, (1), 1-14.

Herwati US \& Agus MSH. (2019). Pendugaan Status Trofik dengan Pendekatan Kelimpahan Fitoplankton dan Zooplankton di Waduk Sengguruh, Karangkates, Lahor, Wlingi Raya dan Wonorejo Jawa Timur. Jurnal Ilmiah Perikanan dan Kelautan, 1, (1), 7-13.

Junaidi M, Nurliah N \& Azhar F. (2018). Struktur Komunitas Zooplankton di Perairan Kabupaten Lombok Utara, Provinsi Nusa Tenggara Barat. Jurnal Biologi Tropis, 18, (2), 159-169.

Kusmeri L \& Rosanti D. (2015). Struktur Komunitas
Zooplankton di Danau Opi Pakabaring Palembang. Sainmatika: Jurnal Ilmiah Matematika dan Ilmu Pengetahuan Alam, 12, (1), 8-20.

Manurung N \& Setyawati TR. (2015). Produktivitas Primer Danau Lait Kecamatan Tayan Hilir Ditinjau dari Kelimpahan dan Kandungan Klorofil-a Fitoplankton. Jurnal Protobiont, 4, (2) 30-39.

Muhsimin, Santoso N \& Hariyadi. (2016). Pengembangan Geopark Ciletuh Berbasis Partisipasi Masyarakat Sebagai Kawasan Geowisata di Kabupaten Sukabumi. Jurnal Manajemen Resort dan Leisure, 13, (1), 55-60.

Nurhasanah RA, Hasan Z, Dhahiyat Y \& Herawati H. (2017). Struktur Komunitas Fitoplankton di Situ Lengkong Panjalu Kabupaten Ciamis, Jawa Barat. Seminar Nasional Tahunan XIV Hasil Penelitian Perikanan dan Kelautan Tahun 2017 (pp.227-234). Yogyakarta: Departemen Perikanan Fakultas Pertanian, Universitas Gajah Mada.

Nurruhwati I, Zahidah \& Sahidin A. (2017). Kelimpahan Plankton di Waduk Cirata Provinsi Jawa Barat. Jurnal Akuatika Indonesia, 2, (2), 102-108.

Pongngarang AI. (2018). Komposisi Jenis dan Kelimpahan Zooplankton di Perairan Kepulauan Tanakeke Kabupaten Takalar. Skripsi. Universitas Hasanudin, Makasar.

Purnamasari PA. (2016). Struktur Komunitas Plankton di Perairan Mangrove Karangsong, Kabupaten Indramayu, Jawa Barat. Jurnal Biologi (Universitas Negeri Yogyakarta), 5, (5), 40-51.

Redjeki S. (2013). Komposisi dan Kelimpahan Ikan di Ekosistem Mangrove di Kedungmalang, Jepara. Jurnal Ilmu Kelautan, 18, (1), 54-60.

Sachlan M. (1982). Planktonologi. Semarang: Fakultas Peternakan dan Perikanan Universitas Pangeran Diponogoro.

Setyawan AD \& Winarno K. (2006). Conservation Problems of Mangrove Ecosystem in Coastal Area of Rembang Regency, Central Java. Biodiversitas : Journal of Biological Diversity, 7, (2), 159-163.

Wardhani NK \& Ihwan A. (2015). Studi Tingkat Keasaman Air Hujan Berdasarkan Kandungan Gas CO2, SO2 dan NO2 di Udara (Studi Kasus Balai Pengamatan Dirgantara Pontianak). Prisma Fisika, 3, (1), 9-14.

Yusanti IA. (2019). Kelimpahan Zooplankton sebagai Indikator Kesuburan Perairan di Rawa Banjiran Desa Sedang Kecamatan Suak Tapeh Kabupaten Banyuasin. Sainmatika : Jurnal Ilmiah Matematika dan Ilmu Pengetahuan Alam, 16, (1), 33-39. 